\title{
Social networks in nursing work processes: an integrative literature review
}

\author{
As redes sociais nos processos de trabalho em enfermagem: revisão integrativa da literatura \\ Las redes sociales en los procesos laborales de enfermería: revisión integrativa de la literatura
}

\author{
Ana Cláudia Mesquita ${ }^{1}$, Cristina Mara Zamarioli ${ }^{1}$, Francine Lima Fulquini ${ }^{1}$, Emilia Campos de Carvalho ${ }^{1}$, \\ Emilia Luigia Saporiti Angerami ${ }^{1}$
}

How to cite this article:

Mesquita AC, Zamarioli CM, Fulquini FL, Carvalho EC, Angerami ELS. Social networks in nursing work processes: an integrative literature review. Rev Esc Enferm USP. 2017;51:e03219. DOI: http://dx.doi.org/10.1590/S1980-220X2016021603219

${ }^{1}$ Universidade de São Paulo, Escola de Enfermagem de Ribeirão Preto, Ribeirão Preto, SP, Brazil.

\begin{abstract}
Objective: To identify and analyze the available evidence in the literature on the use of social networks in nursing work processes. Method: An integrative review of the literature conducted in PubMed, CINAHL, EMBASE and LILACS databases in January 2016, using the descriptors social media, social networking, nursing, enfermagem, redes sociais, mídias sociais, and the keyword nursing practice, without year restriction. Results: The sample consisted of 27 international articles which were published between 2011 and 2016. The social networks used were Facebook (66.5\%), Twitter (30\%) and WhatsApp (3.5\%). In $70.5 \%$ of the studies, social networks were used for research purposes, in $18.5 \%$ they were used as a tool aimed to assist students in academic activities, and in $11 \%$ for executing interventions via the internet. Conclusion: Nurses have used social networks in their work processes such as Facebook, Twitter and WhatsApp to research, teach and watch. The articles show several benefits in using such tools in the nursing profession; however, ethical considerations regarding the use of social networks deserve further discussion.
\end{abstract}

DESCRIPTORS

Nursing; Social Networking; Nursing Informatics; Review. 


\section{INTRODUCTION}

The use of social media has increased exponentially in recent years ${ }^{(1)}$. The world's population has grown from 7 million to 7.2 million, and the number of active internet users has exceeded 3 billion with an increase of 500 million in 2014 alone, reaching $42 \%$ of all humanity ${ }^{(2)}$. Since the advent of the internet, and especially of Web 2.0 technology (the second generation of the World Wide Web that has allowed greater interactivity among users), the number of people who access and use this technology both professionally and recreationally has grown steadily, so that the estimate in 2012 was 2.4 billion users ${ }^{(3)}$.

The definition of "social media" is broad and is constantly evolving ${ }^{(4)}$. Social media can be defined as a variety of internetbased tools that help users connect, collaborate, and communicate with others in real-time ${ }^{(5)}$. Social media sites offer a variety of features that serve different purposes for the users ${ }^{(6)}$ and can be grouped by purpose, such as: professional networking (LinkedIn), media sharing networks (YouTube, Flickr), sites for producing content (blogs [Tumblr, Blogs] and microblogs [Twitter]), information sites (Wikipedia), gaming and virtual reality environments (Second Life) and social networks (Facebook, MySpace, Google Plus, Twitter) ${ }^{(7-9)}$.

Social networks are one of the most widely used forms of social media, providing a convenient platform for sharing information and maintaining contact with people, as well as providing a way of locating and connecting with them where sharing information and communication occurs in a structured way ${ }^{(10)}$. Also, social networks allow professionals to develop and maintain connections with colleagues and peers ${ }^{(11)}$.

The development of online communities using social networks in Nursing has emerged as a driving force in healthcare $^{(12)}$, considering that the benefits of such technology are well-known: real-time exchange of information on healthrelated subjects, attaining research information, the possibility of maintaining contact with patients and their families, reaching new audiences for education and health services, and dissemination of organizational achievements, among others $^{(13)}$. As an example, we can mention the use of Twitter and Facebook by the Royal College of Nursing, Nursing and Midwifery Council UK, and numerous other online communities related to nursing aimed at communicating with the public and at disseminating information ${ }^{(12)}$.

Many people, including nurses, use social networks ${ }^{(1)}$ and their use has increased in health areas ${ }^{(12)}$. At the international level for example, it is known that the use of nursing blogs has been continuously growing ${ }^{(14)}$. Nurses share information through such tools on intervention case studies or consult other health professionals about their experiences ${ }^{(15)}$. It is also known that due to the increasing use of such tools by nurses, international discussions have emerged on the ethical implications regarding the use of social networks in the nursing profession $^{(4,16)}$. However, little is known about the use of such tools in nursing work processes ${ }^{(17)}$, thus highlighting the need to better explore the potential use of social networks in their work processes. In accordance with the literature, our study considers that nursing work processes are comprised of the following activities: to administer, assist, teach, research and to politically participate in their contexts of action ${ }^{(18)}$. It also considers that the use of social networks may be a contributory factor in the performance of these activities.

Thus, an integrative literature review was carried out in the Brazilian context with the objective of identifying the use of social networks in nursing education ${ }^{(19)}$. According to the results, the use of social networks in the area of nursing education has brought several benefits to students, educators, professionals and institutions. However, the researchers of the aforementioned study concluded that studies which report on the experiences of using social networks in nursing education are still scarce, both on national and international levels.

Studies on the use of this tool in other scenarios of the nursing practice were not identified by our means, thus justifying the development of this study focused on nursing work processes. From this perspective, the objective was to identify and analyze available evidence in the literature on the use of social networks in nursing work processes.

\section{METHOD}

This is an integrative review of the literature carried out in the following stages: developing the guiding question; searching for primary studies in databases; extracting data from studies; evaluating the selected studies; analyzing and synthesizing the results, then presenting the review ${ }^{(20)}$. The guiding question was: What is the evidence available in the literature on the use of social networks in nursing work processes?

Data collection was performed in January, 2016. The US National Library of Medicine (PubMed), Cumulative Index to Nursing and Allied Health Literature (CINAHL), Excerpta Medica Database (EMBASE) and Latin American and Caribbean Literature in Health Science (LILACS) databases were consulted for article selection. The descriptors (social media, social networking, nursing, enfermagem, redes sociais, midias sociais) and the keyword (nursing practice) were combined in different ways to ensure a broad search (Chart 1).

Chart 1 - Crossings performed according to the selected databases - Ribeirão Preto, SP, Brazil, 2016.

\begin{tabular}{|c|c|}
\hline \multirow{2}{*}{ Databases } & \multicolumn{1}{|c|}{ Crossings } \\
\hline \multirow{2}{*}{ PUBMED } & Nursing practice AND Social media OR Social networking \\
\cline { 2 - 2 } & Nursing AND Social media OR Social networking \\
\hline \multirow{2}{*}{ CINAHL } & Nursing practice AND Social media OR Social networking \\
\cline { 2 - 2 } & Nursing AND Social media OR Social networking \\
\hline \multirow{2}{*}{ EMBASE } & Nursing practice AND Social media OR Social networking \\
\cline { 2 - 2 } & Nursing AND Social media OR Social networking \\
\hline LILACS & Enfermagem AND Mídias sociais OR Redes sociais \\
\hline
\end{tabular}

The inclusion criteria for pre-selecting the studies were: studies in English, Portuguese or Spanish, published in periodicals and that addressed the use of social networks by nurses in their work processes. According to the exclusion criteria, non-primary articles such as opinion articles and reviews, or those that after reading in full did not respond to the purpose of this review. It is important to emphasize that there was no limitation in relation to the publication year of the articles. The study selection was carried out by a thorough reading of the titles and abstracts so that studies that met the aforementioned inclusion criteria remained 
for final selection. For the final selection, the articles were read in full, and those which presented the use of social networks by a nurse in their work processes were selected.

A validated instrument was used for data collection and analysis $^{(21)}$, adapted to meet the objective of the study. The topics of interest addressed in the instrument were: article title, publication year, language, country of publication, database, objective, method, results, conclusions and level of evidence. The Melnyk and Fineout-Overholt ${ }^{(22)}$ classifying levels of evidence was used, which classifies studies into seven levels: 1 - evidence from a systematic review of all relevant randomized controlled trials (RCT's), or evidencebased clinical practice guidelines based on systematic reviews of RCT's; 2 - evidence from at least one well-designed randomized controlled trial; 3 - evidence obtained from welldesigned controlled trials without randomization, quasiexperimental; 4 - evidence from well-designed cohort and case-control studies; 5 - evidence from systematic reviews of descriptive and qualitative studies; 6 - evidence derived from a single descriptive or qualitative study; 7 - evidence from the opinion of authorities and/or reports of expert committees. According to this classification, levels 1 and 2 are considered strong evidence, 3 and 4 moderate and 5 to 7 weak evidence.

The process of identification, selection and inclusion of the primary studies was carried out in three stages. In the first stage, duplicate articles were excluded; thus, 888 articles were removed from the total of 3,137 articles. In the second stage, titles and abstracts of the 2,249 articles were read based on the inclusion criteria, leading to 75 articles selected. In the third stage, all 75 articles were read (in full), where 48 articles were excluded for not meeting the inclusion criteria and not responding to the guiding question of this review; as a result, the final sample consisted of 27 articles. Figure 1 illustrates the article selection process of this integrative review.

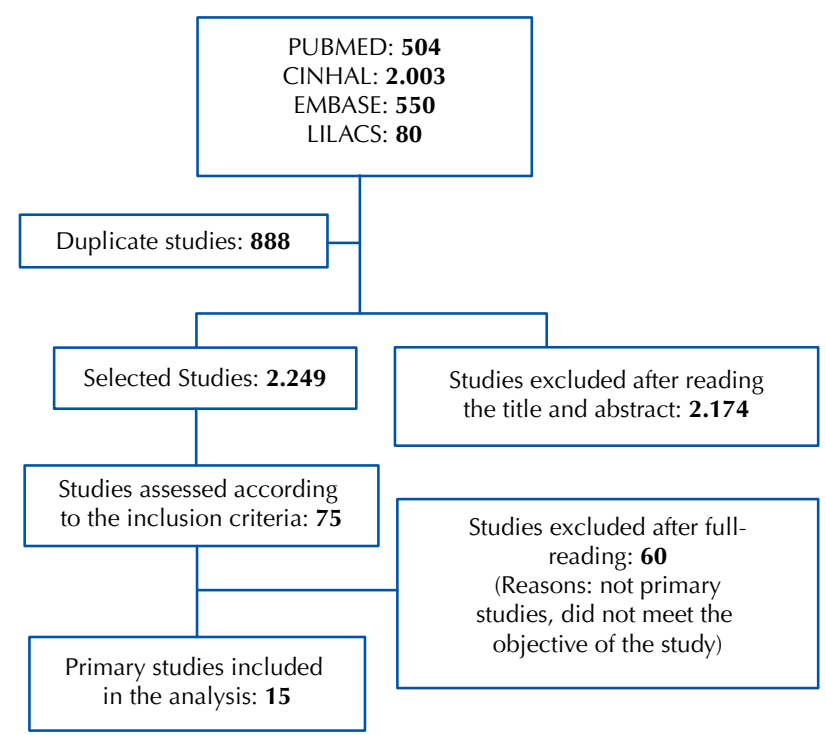

Figure 1 - Flowchart on the identification, selection and inclusion of integrative review studies - Ribeirão Preto, SP, Brazil, 2016.

\section{RESULTS}

The final sample consisted of 27 articles with the oldest published in 2011 and the most recent in 2016; 12 (44.5\%) were published in 2015 , nine $(33.5 \%)$ in 2014 , two (7.5 $\%)$ in 2013, two (7.5\%) in 2012, one (3.5\%) in 2011 and one (3.5\%) in 2016. They were published in English and in international journals. We identified that the authors of the studies, or at least one of them, belonged to nursing departments or schools.

As to the location of the studies, 11 (41\%) were performed in the United States, three (11.3\%) in the United Kingdom, three (11.3\%) in Canada, two (7.5\%) in Australia, one (3.5\%) in the Philippines, one (3.5\%) in South Africa, one (3.5\%) in Spain, one (3.5\%) in Finland, and one (3.5\%) jointly in both Italy and the United Kingdom. The location was not reported in three (11.3\%) studies. The most frequent designs were cross-sectional studies with 16 studies (59.5\%), and qualitative studies with six studies (22\%), followed by the mixed method with two studies (7.5\%), randomized clinical trial with two studies (7.5\%), and one (3.5\%) observational study. Therefore, 25 studies $(92.5 \%)$ presented an evidence level of 6 (weak), and two (7.5\%) presented an evidence level of 2 (strong).

Regarding the study population, the samples were composed of: nursing and medical students, healthy young people aged 15 to 24 years, families, children and adolescents with Klinefelter's syndrome, nurses and physicians, mothers with advanced maternal age, smokers, parental caregivers of children and adolescents with cancer, patients with schizophrenia and their caregivers, African-American women, lactating mothers of preterm infants, young adult survivors of cancer and caregivers of patients in palliative care.

The social networks used were Facebook (18 studies; 66.5\%), Twitter (8 studies; 30\%) and WhatsApp (1 study; $3.5 \%)$, by way of consulting profiles and public posts for data collection (48\%); creating online groups for educational purposes (22\%); publishing advertisements, videos and/or messages for the purpose of recruiting participants for research (15\%); sending messages to research participants (7\%) and providing informative/educational content (4\%).

The studies selected for this review were divided into three groups according to the purpose for which the social networks were used and considering the work processes of the nurse practitioner: research, teaching and assistance. Nineteen studies (70.5\%) used social networks for research purposes through data collection in public profiles, recruiting participants and for following-up participants in a longitudinal study. Regarding teaching-related activities, five articles $(18.5 \%)$ used social networks as a tool to help students in academic activities achieved through sharing academic content and discussions in social networks. Three studies (11\%) used social networks for assistance by implementing Internet interventions via sharing informative content or by sending messages to the participants.

It should be noted that one of the aspects that permeates the activities of professionals is the ethical issue in relation to the subject under study. In this sense, only two studies 
addressed it. One of the articles presented a discussion about the implications of nurses using social networks for posting personal content ${ }^{(23)}$, and another article addressed the ethical issue of data collection from public social networking profiles ${ }^{(24)}$.

Among the results and benefits mentioned about using Facebook, it can be noted that this social network can be useful for identifying risk conditions, such as those related to stress in undergraduate students; disseminating information; contributing to students' learning with educational activities; promoting positive behavioral changes; improving participants' adherence in longitudinal studies through contact that Facebook provides; recruiting participants for research, especially in younger age group populations; helping young adults quit tobacco use through support groups in this social network; acting as a platform for communication and support among individuals in a particular situation, such as people with schizophrenia and their caregivers, nursing mothers of preterm infants, or caregivers of palliative care patients.

Regarding articles that used Twitter, there are indications that this social network represents a recruiting tool that allows for involving populations which are difficult to reach, and it guarantees study participants transparency regarding research and anonymity, in addition to apparently being a more accessible method for participation in health studies. Twitter can also be useful in disseminating content about public health education, it can contribute to the student learning process and to the development of the nursing profession through sharing of opinions, knowledge and clinical experience.

According to the article that used WhatsApp, this tool allows for using virtual space for collaborative practice and for sharing information.

Chart 2 - Summary-chart of the study characteristics included in the review according to authors, title of the article, publication year, social network studied, main results, and recommendations and conclusions - Ribeirão Preto, SP, Brazil, 2016.

\begin{tabular}{|c|c|c|c|}
\hline Authors/Title of the article/Year & Social network studied & Main Results & Recommendations/Conclusions \\
\hline $\begin{array}{l}\text { Egan KG, Moreno MA. Prevalence } \\
\text { of stress references on college } \\
\text { freshmen facebook profiles. } \\
2011^{(24)}\end{array}$ & $\begin{array}{l}\text { Undergraduate profiles on Face- } \\
\text { book were used for gathering in- } \\
\text { formation regarding stress, weight } \\
\text { concerns, depression symptoms } \\
\text { and alcohol use. }\end{array}$ & $\begin{array}{l}\text { A positive association was found } \\
\text { between stress and weight con- } \\
\text { cerns and depression symptoms. }\end{array}$ & $\begin{array}{l}\text { Facebook can be useful to identify } \\
\text { students at risk of stress-related } \\
\text { conditions and for disseminating } \\
\text { information about the capabilities } \\
\text { of the university for those students. }\end{array}$ \\
\hline $\begin{array}{l}\text { Jones K, Baldwin KA, Lewis PR. } \\
\text { The potential influence of a social } \\
\text { media intervention on risky sexual } \\
\text { behavior and Chlamydia inci- } \\
\text { dence. } 2012^{(25)}\end{array}$ & $\begin{array}{l}\text { A group of community health } \\
\text { nurses developed a Facebook page } \\
\text { that offered information about } \\
\text { Chlamydia. }\end{array}$ & $\begin{array}{l}\text { According to the results, an } \\
\text { increase of } 23 \% \text { was found on } \\
\text { self-reported use of condoms by } \\
\text { young people in sexual intercourse } \\
\text { and a } 54 \% \text { reduction in cases of } \\
\text { chlamydia among the participants } \\
\text { from } 15 \text { to } 17 \text { years. }\end{array}$ & $\begin{array}{l}\text { The study results support that } \\
\text { social media can be an effective } \\
\text { mechanism for disseminating } \\
\text { information and promoting positive } \\
\text { behavior changes among the study } \\
\text { population. }\end{array}$ \\
\hline $\begin{array}{l}\text { Mychasiuk R, Benzies K. Facebook: } \\
\text { an effective tool for participant } \\
\text { retention in longitudinal research. } \\
2012^{(26)}\end{array}$ & $\begin{array}{l}\text { Facebook was used in a longitudi- } \\
\text { nal follow-up study as a search tool } \\
\text { for the participants who were not } \\
\text { being located. }\end{array}$ & $\begin{array}{l}\text { Found } 19 \text { participants who had been } \\
\text { "lost" for follow-up, decreasing the } \\
\text { loss of study subjects by } 16 \% \text {. }\end{array}$ & $\begin{array}{l}\text { The researchers suggest that } \\
\text { Facebook is an effective means to } \\
\text { improve participation of subjects in } \\
\text { a longitudinal intervention study. }\end{array}$ \\
\hline $\begin{array}{l}\text { Close S, Smaldone A, Fennoy I, } \\
\text { Reame N, Grey M. Using informa- } \\
\text { tion technology and social net- } \\
\text { working for recruitment of research } \\
\text { participants: experience from an } \\
\text { exploratory study of pediatric } \\
\text { Klinefelter syndrome. } 2013^{(27)}\end{array}$ & $\begin{array}{l}\text { Social networks were used as a } \\
\text { way to have easier access to hard } \\
\text { to reach participants for participa- } \\
\text { tion recruitment in research. }\end{array}$ & $\begin{array}{l}\text { Recruitment through invitation } \\
\text { melee in a clinical environment } \\
\text { achieved } 9 \% \text { of participants for } \\
\text { research, as } 91 \% \text { joined the study } \\
\text { through social networks. One of } \\
\text { the most successful approaches } \\
\text { used was an announcement on } \\
\text { Facebook. }\end{array}$ & $\begin{array}{l}\text { The use of web-based technologies } \\
\text { increases recruitment of hard-to- } \\
\text { reach populations. Budgets for } \\
\text { research funding should include } \\
\text { expenditure on website registration } \\
\text { and maintenance fees, as well as } \\
\text { online ads on social networking } \\
\text { websites. }\end{array}$ \\
\hline $\begin{array}{l}\text { Santillán García A. Impact of } \\
\text { diffusion of the methodology of } \\
\text { evidence-based nursing through } \\
\text { Facebook. } 2013^{(28)}\end{array}$ & $\begin{array}{l}\text { The Facebook page "Evidence- } \\
\text { Based Nursing" was used to evalu- } \\
\text { ate the impact of disseminating } \\
\text { content through its content. }\end{array}$ & $\begin{array}{l}\text { Approximately } 76 \% \text { of participants } \\
\text { say they have improved their knowl- } \\
\text { edge in terms of evidence-based } \\
\text { practices after reading the page. }\end{array}$ & $\begin{array}{l}\text { The page has contributed to } \\
\text { improving knowledge about } \\
\text { evidence-based practices. It is nec- } \\
\text { essary to investigate the functioning } \\
\text { of social networks for this purpose. }\end{array}$ \\
\hline $\begin{array}{l}\text { Child RJ, Mentes JC, Pavlish C, } \\
\text { Phillips LR. Using Facebook and } \\
\text { participant information clips to } \\
\text { recruit emergency nurses for } \\
\text { research. 2014 (29) }\end{array}$ & $\begin{array}{l}\text { A video was recorded to recruit } \\
\text { participants for research and was } \\
\text { posted in certain Facebook groups } \\
\text { (nursing groups in urgency and } \\
\text { emergency). }\end{array}$ & $\begin{array}{l}\text { The main benefits of using Facebook } \\
\text { were: great dissemination of the vid- } \\
\text { eo; large number of people reached } \\
\text { in little time (almost half of the total } \\
\text { of participants was achieved in less } \\
\text { than } 72 \text { h); low cost. }\end{array}$ & $\begin{array}{l}\text { The use of Facebook for the recruit- } \\
\text { ing younger nurses was success- } \\
\text { ful. The researchers should not } \\
\text { overlook the use of social networks } \\
\text { for recruitment in research. }\end{array}$ \\
\hline $\begin{array}{l}\text { O'Connor A, Jackson L, Gold- } \\
\text { smith L, Skirton H. Can I get a } \\
\text { retweet please? Health research } \\
\text { recruitment and the Twittersphere. } \\
2014^{(30)}\end{array}$ & $\begin{array}{l}\text { An invitation to a survey was pub- } \\
\text { licized on Twitter which had a link } \\
\text { that directed the participants to the } \\
\text { online questionnaire. }\end{array}$ & $\begin{array}{l}\text { Over the course of } 11 \text { weeks, a } \\
\text { total of } 529 \text { people accessed the } \\
\text { survey. The study was fully popu- } \\
\text { lated by } 299(56.5 \%) \text { participants. }\end{array}$ & $\begin{array}{l}\text { Twitter is an effective means in } \\
\text { terms of recruitment cost and al- } \\
\text { lows for participation of hard-to- } \\
\text { reach populations. }\end{array}$ \\
\hline $\begin{array}{l}\text { Labrague LJ. Facebook use and } \\
\text { adolescents emotional states of } \\
\text { depression, anxiety, and stress. } \\
2014^{(31)}\end{array}$ & $\begin{array}{l}\text { Facebook was used for an inves- } \\
\text { tigation regarding the emotional } \\
\text { state of youth (depression, anxiety, } \\
\text { and stress). }\end{array}$ & $\begin{array}{l}\text { No relationship was found between } \\
\text { the intensity of using Facebook and } \\
\text { symptoms of anxiety, depression } \\
\text { and stress. Time spent on the social } \\
\text { network was linked to depression } \\
\text { and anxiety symptoms. }\end{array}$ & $\begin{array}{l}\text { The intensity of using Facebook } \\
\text { is not directly related to negative } \\
\text { emotional states, but the time spent } \\
\text { on it is related to an increase in } \\
\text { depression and anxiety scores. }\end{array}$ \\
\hline
\end{tabular}




\begin{tabular}{|c|c|c|c|}
\hline Authors/Title of the article/Year & Social network studied & Main Results & Recommendations/Conclusions \\
\hline $\begin{array}{l}\text { Struik LL, Baskerville NB. The role } \\
\text { of Facebook in Crush the Crave, a } \\
\text { mobile- and social media-based } \\
\text { smoking cessation intervention: } \\
\text { qualitative framework analysis of } \\
\text { posts. } 2014^{(32)}\end{array}$ & $\begin{array}{l}\text { The researchers used Facebook to } \\
\text { characterize the message content } \\
\text { of a page about quitting smoking } \\
\text { aimed at young adults. }\end{array}$ & $\begin{array}{l}71 \% \text { of the original messages sup- } \\
\text { ported stopping smoking. }\end{array}$ & $\begin{array}{l}\text { The results indicate that social } \\
\text { networking websites, especially } \\
\text { Facebook, justifies their inclusion } \\
\text { in efforts to control tobacco use } \\
\text { targeted towards young adults. }\end{array}$ \\
\hline $\begin{array}{l}\text { Moorley CR, Chinn T. Supporting } \\
\text { student nurses in practice with } \\
\text { additional online communication } \\
\text { tools. } 2014^{(12)}\end{array}$ & $\begin{array}{l}\text { Twitter was used to evaluate the } \\
\text { user experience of this social } \\
\text { network to create a nursing com- } \\
\text { munity online. }\end{array}$ & $\begin{array}{l}\text { There has been a significant } \\
\text { increase in the use of Twitter by } \\
\text { nurses since } 2011 \text {, which became } \\
\text { a space that is centered on sharing } \\
\text { opinions, knowledge and clinical } \\
\text { experience. }\end{array}$ & $\begin{array}{l}\text { Nurses have used social network- } \\
\text { ing for their own development. } \\
\text { Health employers need to encour- } \\
\text { age the use of social networks } \\
\text { to help develop knowledge and } \\
\text { experience in nursing practice. }\end{array}$ \\
\hline $\begin{array}{l}\text { Tower M, Latimer S, Hewitt, J. } \\
\text { Social networking as a learning } \\
\text { tool: nursing students' perception } \\
\text { of efficacy. } 2014^{(33)}\end{array}$ & $\begin{array}{l}\text { Facebook was used to examine } \\
\text { the perception of nursing students } \\
\text { on the effectiveness of this social } \\
\text { network as a tool to aid in their } \\
\text { studies. }\end{array}$ & $\begin{array}{l}\text { Students considered the group as } \\
\text { an innovative method to support } \\
\text { the study, in addition to being use- } \\
\text { ful in promoting learning and peer } \\
\text { involvement. }\end{array}$ & $\begin{array}{l}\text { Social networks like Facebook } \\
\text { have the potential to increase self- } \\
\text { efficacy of students in learning and } \\
\text { can support students to develop } \\
\text { their learning. }\end{array}$ \\
\hline $\begin{array}{l}\text { Levati, S. Professional conduct } \\
\text { among registered nurses in the use } \\
\text { of online social networking sites. } \\
2014^{(23)}\end{array}$ & $\begin{array}{l}\text { Facebook was used to explore the } \\
\text { use of social networks for nurses in } \\
\text { Italy and in the United Kingdom, } \\
\text { focusing on disclosure of personal } \\
\text { and professional information. }\end{array}$ & $\begin{array}{l}\text { Nurses use the social network in a } \\
\text { similar way and tend to promote } \\
\text { professional and personal informa- } \\
\text { tion. Unprofessional content was } \\
\text { also found (use of alcohol, nudity } \\
\text { and sexual content). }\end{array}$ & $\begin{array}{l}\text { Most analyzed nurses seemed } \\
\text { aware of the risks of exposure in } \\
\text { social networks; however, their } \\
\text { online activity indicates blurring } \\
\text { of their personal and professional } \\
\text { lives. }\end{array}$ \\
\hline $\begin{array}{l}\text { Mckay M, Sanko JS, Shekhter I, } \\
\text { Birnbach DJ. Twitter as a tool to en- } \\
\text { hance student engagement during } \\
\text { an interprofessional patient safety } \\
\text { course. } 2014^{(34)}\end{array}$ & $\begin{array}{l}\text { Twitter was used as a method } \\
\text { to promote the involvement of } \\
\text { students in an interprofessional } \\
\text { patient safety course. }\end{array}$ & $\begin{array}{l}\text { This social network successfully } \\
\text { and informally captured conversa- } \\
\text { tions and experiences of students, } \\
\text { which would not have been } \\
\text { achieved otherwise. }\end{array}$ & $\begin{array}{l}\text { Twitter promoted greater involve- } \\
\text { ment among the students in } \\
\text { the course. Future educational } \\
\text { programming for interprofessional } \\
\text { courses should consider the use of } \\
\text { social networks. }\end{array}$ \\
\hline $\begin{array}{l}\text { Morley DA. Supporting student } \\
\text { nurses in practice with addi- } \\
\text { tional online communication tools. } \\
2014^{(35)}\end{array}$ & $\begin{array}{l}\text { Facebook was used to explore the } \\
\text { possibility of strengthening clinical } \\
\text { learning through the use of support } \\
\text { groups on the web for nursing } \\
\text { students. }\end{array}$ & $\begin{array}{l}\text { The results indicate a high level of } \\
\text { academic support and interactivity } \\
\text { among Facebook users. }\end{array}$ & $\begin{array}{l}\text { Facebook can be a useful tool in } \\
\text { certain academic programs. Stu- } \\
\text { dents need to be mature and aware } \\
\text { of their need for learning to use the } \\
\text { support groups on Facebook in a } \\
\text { profitable way. }\end{array}$ \\
\hline $\begin{array}{l}\text { Booth RG. Happiness, stress, a bit } \\
\text { of vulgarity, and lots of discursive } \\
\text { conversation: a pilot study examin- } \\
\text { ing nursing students' tweets about } \\
\text { nursing education posted to Twitter. } \\
2015^{(36)}\end{array}$ & $\begin{array}{l}\text { Twitter was used to explore how } \\
\text { nursing students describe the ele- } \\
\text { ments of their training in nursing } \\
\text { through this social network. }\end{array}$ & $\begin{array}{l}\text { The messages from the students } \\
\text { contained a variety of elements } \\
\text { related to education in nursing, } \\
\text { including events and experience } \\
\text { reports. Messages reporting stress } \\
\text { were also observed. }\end{array}$ & $\begin{array}{l}\text { The results highlight the growing } \\
\text { requirement of knowledge of social } \\
\text { networks by nursing educators, as } \\
\text { well as its use by students in order } \\
\text { to better develop the learning op- } \\
\text { portunities. }\end{array}$ \\
\hline $\begin{array}{l}\text { McDaniel PA, Patzke } \mathrm{H} \text {, Malone } \\
\text { RE. Twitter users' reaction to a } \\
\text { chain pharmacy's decision to end } \\
\text { tobacco sales. } 2015^{(37)}\end{array}$ & $\begin{array}{l}\text { Twitter was used to find out how } \\
\text { users of this social network re- } \\
\text { sponded to the announcement that } \\
\text { a pharmacy chain was stopping } \\
\text { tobacco sales. }\end{array}$ & $\begin{array}{l}\text { Most of the tweets were messages } \\
\text { either supporting the initiative } \\
(56.0 \%) \text { or were neutral messages } \\
(39.4 \%) \text {. }\end{array}$ & $\begin{array}{l}\text { There was little criticism regarding } \\
\text { the decision of stopping tobacco } \\
\text { sales among Twitter users. }\end{array}$ \\
\hline $\begin{array}{l}\text { Tower M, Blacklock E, Watson } \\
\text { B, Heffernan C, Tronoff G. Using } \\
\text { social media as a strategy to ad- } \\
\text { dress 'sophomore slump' in second } \\
\text { year nursing students: A qualitative } \\
\text { study. } 2015^{(38)}\end{array}$ & $\begin{array}{l}\text { Facebook was used to develop a } \\
\text { forum that used peer learning to } \\
\text { build self-efficacy related to learn- } \\
\text { ing in nursing students. }\end{array}$ & $\begin{array}{l}\text { The students shared experiences, } \\
\text { used verbal persuasion to reframe } \\
\text { issues and suggested that this } \\
\text { helped in building self-efficacy } \\
\text { related to learning. }\end{array}$ & $\begin{array}{l}\text { Social networks are important tools } \\
\text { by which students can engage with } \\
\text { their peers to learn how to build } \\
\text { self-efficacy around their studies. }\end{array}$ \\
\hline $\begin{array}{l}\text { Akard TF, Wray S, Gilmer MJ. } \\
\text { Facebook advertisements recruit } \\
\text { parents of children with cancer } \\
\text { for an online survey of web-based } \\
\text { research preferences. } 2015^{(39)}\end{array}$ & $\begin{array}{l}\text { Facebook was used to examine the } \\
\text { feasibility of using ads on recruiting } \\
\text { parent caregivers of children and } \\
\text { adolescents with cancer to partici- } \\
\text { pate in research. }\end{array}$ & $\begin{array}{l}\text { Of } 284 \text { individuals screened, } 106 \\
\text { were eligible. } 45 \text { caregivers of } \\
\text { children with cancer concluded the } \\
\text { research. The parents had the tech- } \\
\text { nological capacity to participate in } \\
\text { research through the internet and } \\
\text { preferred this methodology. }\end{array}$ & $\begin{array}{l}\text { According to the results, recruit- } \\
\text { ment methods and data collection } \\
\text { via the web are useful and inex- } \\
\text { pensive. Facebook was an effective } \\
\text { method to recruit a diverse sample } \\
\text { of parent caregivers of children and } \\
\text { adolescents with cancer. }\end{array}$ \\
\hline
\end{tabular}

continued... 


\begin{tabular}{|c|c|c|c|}
\hline Authors/Title of the article/Year & Social network studied & Main Results & Recommendations/Conclusions \\
\hline $\begin{array}{l}\text { Athanasopoulou C, Sakellari E. } \\
\text { Facebook and Health Information: } \\
\text { content analysis of Groups related } \\
\text { to schizophrenia. } 2015^{(40)}\end{array}$ & $\begin{array}{l}\text { Facebook was used to analyze } \\
\text { pages related to schizophrenia. }\end{array}$ & $\begin{array}{l}\text { The main goal of most of the } \\
\text { groups was to create awareness } \\
\text { and support for people with schizo- } \\
\text { phrenia and their caregivers. }\end{array}$ & $\begin{array}{l}\text { Groups related to schizophrenia } \\
\text { and other mental disorders are } \\
\text { essential. It can be an important } \\
\text { communication platform and sup- } \\
\text { port for people with the disease } \\
\text { and their caregivers. }\end{array}$ \\
\hline $\begin{array}{l}\text { Joseph RP, Keller C, Adams MA, } \\
\text { Ainsworth BE. Print versus a cul- } \\
\text { turally-relevant Facebook and text } \\
\text { message delivered intervention to } \\
\text { promote physical activity in African } \\
\text { American women: a randomized } \\
\text { pilot trial. } 2015^{(41)}\end{array}$ & $\begin{array}{l}\text { Facebook was used to promote the } \\
\text { practice of physical activity among } \\
\text { African-American women. }\end{array}$ & $\begin{array}{l}\text { The physical activity program of- } \\
\text { fered via messages was associated } \\
\text { with decreased sedentary behavior, } \\
\text { increased intensity of physical } \\
\text { activity, enhanced psychosocial } \\
\text { outcomes and high satisfaction of } \\
\text { the participants. }\end{array}$ & $\begin{array}{l}\text { The study provides important sub- } \\
\text { sidies on the efficacy, acceptability } \\
\text { and feasibility of the use of social } \\
\text { networks to promote physical activ- } \\
\text { ity in African-American women. }\end{array}$ \\
\hline $\begin{array}{l}\text { Niela-Vilén H, Axelin A, Melender } \\
\text { HL, Salanterä S. Aiming to be a } \\
\text { breastfeeding mother in a neonatal } \\
\text { intensive care unit and at home: A } \\
\text { thematic analysis of peer-support } \\
\text { group discussion in social media. } \\
2015^{(42)}\end{array}$ & $\begin{array}{l}\text { Facebook was used to describe the } \\
\text { perceptions of lactating mothers of } \\
\text { premature babies through posts in } \\
\text { support group discussions of this } \\
\text { social network. }\end{array}$ & $\begin{array}{l}\text { Three main themes were identified: } \\
\text { the paradox of breastfeeding in } \\
\text { the hospital, the "reality check" } \\
\text { of breastfeeding at home and the } \\
\text { experience of breastfeeding as part } \\
\text { of being a mother. }\end{array}$ & $\begin{array}{l}\text { Mothers of premature infants } \\
\text { require advice on breastfeeding } \\
\text { and support in neonatal intensive } \\
\text { care units and at home. The sup- } \\
\text { port groups on social networks } \\
\text { can help mothers to have access to } \\
\text { the necessary encouragement and } \\
\text { support. }\end{array}$ \\
\hline $\begin{array}{l}\text { Odlum M, Yoon S. What can we } \\
\text { learn about the Ebola outbreak } \\
\text { from tweets? } 2015^{(43)}\end{array}$ & $\begin{array}{l}\text { Twitter was used as a means of } \\
\text { real-time surveillance of outbreaks } \\
\text { of Ebola and to examine knowl- } \\
\text { edge and public attitudes on the } \\
\text { subject. }\end{array}$ & $\begin{array}{l}\text { The tweets began increasing in } \\
\text { Nigeria 3-7 days before the official } \\
\text { announcement of the first case } \\
\text { of Ebola. The topics discussed } \\
\text { in tweets included risk factors, } \\
\text { preventive education and disease } \\
\text { trends. }\end{array}$ & $\begin{array}{l}\text { The results provide information on } \\
\text { the intersection of social networks } \\
\text { and outbreaks of public health } \\
\text { surveillance. Twitter can be useful } \\
\text { to inform and promote education } \\
\text { in public health. }\end{array}$ \\
\hline $\begin{array}{l}\text { Valle CG, Tate DF, Mayer DK, Alli- } \\
\text { cock M, Cai J. Exploring Mediators } \\
\text { of Physical Activity in Young Adult } \\
\text { Cancer Survivors: Evidence from a } \\
\text { Randomized Trial of a Facebook- } \\
\text { Based Physical Activity Interven- } \\
\text { tion. } 2015^{(44)}\end{array}$ & $\begin{array}{l}\text { Facebook was used as a means for } \\
\text { supporting young adult cancer sur- } \\
\text { vivors to participate in a physical } \\
\text { activity program. }\end{array}$ & $\begin{array}{l}\text { Social support from friends and } \\
\text { self-evaluation were positively as- } \\
\text { sociated with changes in moderate } \\
\text { to vigorous physical activity. }\end{array}$ & $\begin{array}{l}\text { The proposals do not explain the } \\
\text { positive effects of the intervention } \\
\text { based on Facebook about physical } \\
\text { activity. Future interventions for } \\
\text { physical activities with young sur- } \\
\text { vivors must aim at social support } \\
\text { from friends and self-evaluation. }\end{array}$ \\
\hline $\begin{array}{l}\text { Wittenberg-Lyles E, et al. "It is the } \\
\text { 'starting over' part that is so hard": } \\
\text { Using an online group to support } \\
\text { hospice bereavement. } 2015^{(45)}\end{array}$ & $\begin{array}{l}\text { Facebook was used to evaluate the } \\
\text { potential of a page of this social } \\
\text { network for support for the mourn- } \\
\text { ing of caregivers of patients in } \\
\text { palliative care. }\end{array}$ & $\begin{array}{l}\text { The caregivers shared experi- } \\
\text { ences of loss by encouraging other } \\
\text { people to manage their conflicts. } \\
\text { Anxiety and depression of the } \\
\text { caregivers were lower after the } \\
\text { intervention. }\end{array}$ & $\begin{array}{l}\text { The use of bereavement sup- } \\
\text { port groups on Facebook can be } \\
\text { helpful to caregivers of patients in } \\
\text { palliative care. The positive results } \\
\text { from the use of this social network } \\
\text { associated to support for mourning } \\
\text { should be explored. }\end{array}$ \\
\hline $\begin{array}{l}\text { Willemse JJ. Undergraduate nurses } \\
\text { reflections on WhatsApp use in } \\
\text { improving primary health care } \\
\text { education. } 2015^{(46)}\end{array}$ & $\begin{array}{l}\text { WhatsApp was used to analyze the } \\
\text { experiences of nursing students } \\
\text { about improving education in } \\
\text { primary health care. }\end{array}$ & $\begin{array}{l}\text { Seven themes were identified: posi- } \\
\text { tive experiences, utility to integrate } \\
\text { theory and practice, availability } \\
\text { of resources, opportunity for clari- } \\
\text { fication, anonymity, exclusion of } \\
\text { students for lack of an appropriate } \\
\text { device and speed of execution. }\end{array}$ & $\begin{array}{l}\text { These results could be used to } \\
\text { inform about the use of social } \\
\text { networking applications in teach- } \\
\text { ing and learning, with the aim to } \\
\text { strengthen the integration of theory } \\
\text { and practice. }\end{array}$ \\
\hline $\begin{array}{l}\text { Waldrop J, Wink D. Twitter: An Ap- } \\
\text { plication to Encourage Information } \\
\text { Seeking Among Nursing Students. } \\
2016^{(47)}\end{array}$ & $\begin{array}{l}\text { Twitter was used to stimulate medi- } \\
\text { cal and nursing students to further } \\
\text { explore clinical and professional } \\
\text { issues. }\end{array}$ & $\begin{array}{l}75 \% \text { of participants demonstrated a } \\
\text { willingness to follow links in tweets } \\
\text { to get more information, and } 87 \% \\
\text { wished to receive the tweets even } \\
\text { after the end of the semester. }\end{array}$ & $\begin{array}{l}\text { Twitter can be useful in encour- } \\
\text { aging students to deepen their } \\
\text { knowledge. }\end{array}$ \\
\hline $\begin{array}{l}\text { Richardson J, Grose J, Nelmes P, } \\
\text { Parra G, Linares M. Tweet if you } \\
\text { want to be sustainable: a thematic } \\
\text { analysis of a Twitter chat to discuss } \\
\text { sustainability in nurse education. } \\
2016^{(48)}\end{array}$ & $\begin{array}{l}\text { Twitter was used as a vehicle for } \\
\text { discussing the concept of sustain- } \\
\text { ability in nursing. }\end{array}$ & $\begin{array}{l}\text { Various topics related to the } \\
\text { sustainable use of health resources } \\
\text { and the need to reduce waste was } \\
\text { evident. }\end{array}$ & $\begin{array}{l}\text { Social networks are an effective } \\
\text { way to engage nurses and students } \\
\text { in discussions about issues that are } \\
\text { crucial to the healthcare industry. }\end{array}$ \\
\hline
\end{tabular}

\section{DISCUSSION}

The results of this integrative review indicate that studies on the use of social networks in nursing work processes are recent, as the oldest article selected for this study was published in 2011. It is also possible to identify that the number of studies on this theme has grown each year. As to the origin of the studies, all were produced internationally, which shows the scarcity of national studies on the subject in question. Regarding the level of evidence from the sample studies, the majority (92.5\%) were classified as weak. Despite studies showing a positive position regarding the use of social networks in nursing work processes, it is necessary to develop studies with more robust levels of evidence in order to verify the effectiveness of the use of such tools, especially when these are used as a means for the application of nursing interventions. 
Regarding the target population of the studies selected for this review, it can be noticed that social networks have been used by the most different profiles of individuals, from undergraduate students and health professionals to caregivers and patients with the most diverse diseases. There are reports that people of both sexes of the most varied age groups and races spend more time on social networks than on any other category of websites, whether on computers or on mobile devices ${ }^{(49)}$. Thus, as social networks are used so frequently and by so many people, they are a means of reaching diverse populations that one wishes to study.

Among the social networks addressed in the articles selected for this review, the most used was Facebook, followed by Twitter and WhatsApp. Launched in 2004, Facebook is a platform in which users can establish a virtual identity and connect with people, themes and groups who they consider relevant ${ }^{(29)}$. Facebook allows its users to create personal profiles, where they can exchange messages, photos and frequent updates on their daily personal status with other users $^{(25)}$. It is one of the most popular social networks, with more than 1 billion users worldwide ${ }^{(31)}$.

Twitter is a social networking website that allows users to connect with each other via short messages of up to 140 characters, known as tweets ${ }^{(30)}$. Despite it still being something new to many, Twitter or Twttr (as it was originally known) was launched as a media platform in 2006, and according to company data, Twitter currently has 320 million active monthly users worldwide ${ }^{(50)}$. Through its short messages, Twitter has become an ideal way to communicate quickly and briefly. Users can send tweets to share online materials, such as links to images, blogs and videos with their own followers. This can all be done from a computer, tablet or mobile phone device, increasing its value as a "realtime" tool ${ }^{(30)}$.

WhatsApp is an application where instant messaging is exchanged via the internet, it is considered particularly relevant in contexts with little resources, as it is currently one of the most widely used applications on mobile phones and computers $^{(46)}$. This application allows sending and receiving text messages and other types of media (videos, voice messages, photos) and it also allows for creating chat groups, thus allowing multiple users to participate at the same time in the same group conversation ${ }^{(51)}$. Apps provide the functionality of a website in a mobile-compatible format and can be run independently of web-based browsers by storing information on the device where they are installed ${ }^{(52)}$.

Regarding purpose of use, the articles selected for this review used social networks for research purposes, as a tool to aid in academic activities through providing informative content and creating online discussion groups for academic matters, or for accomplishing interventions also by providing informative content and for messaging research participants.

Regarding data collection from social networks, one of their facilities is the fact that there are profiles whose content is publicly available with no viewing restrictions, allowing for information to be collected ${ }^{(23)}$. According to the literature, recruiting participants for research through social networks presents advantages such as reaching a large number of people in a short period of time and low cost, as well as being an effective way to communicate with participants ${ }^{(26,29,39)}$. Future researchers should not ignore social networks as a recruitment methodology unless the demographic data of the population to be investigated and the study theme do not allow the use of such tools ${ }^{(29)}$. Another advantage that must be taken into account regarding the use of social networks for research is the ease of access to the population under study, in particular those populations who are difficult to reach, which applies both to recruiting participants and to implementing online interventions ${ }^{(25,39)}$.

Concerning adherence of participants in longitudinal studies, social networks can be of great help, since this is one of the main challenges for studies with this design type ${ }^{(26)}$. Participants often cannot be located by researchers due to a change in phone number or address, for example, which may imply in a loss of subjects and consequently impair the study. In this context, social networking websites such as Facebook can be a valuable tool for locating and communicating with research participants ${ }^{(26)}$.

Social networking websites have emerged as an important tool for health studies ${ }^{(24)}$. However, the ethical considerations of this new investigation method deserve further discussions. Conducting studies that use social networking websites raise several concerns, including the social value of this research, fair subject selection, confidentiality, privacy, and informed consent ${ }^{(53)}$. Studies involving the observation of public behavior on social networking websites can be compared to observing human interactions in a public setting, such as a park. Thus, interactions can be observed, despite participants not being aware that they are subjects of research ${ }^{(54)}$. However, in contrast to observations at a public park, social networking users like Facebook have the option of making their content available to the public or restricting their accessibility through privacy settings ${ }^{(53)}$.

Also in the context of using social networks for developing research, one of the studies of this review aimed at evaluating the use of Facebook by nurses in Italy and the United Kingdom ${ }^{(23)}$. The researchers identified the disclosure of potentially unprofessional information regarding alcohol, nudity, and vulgar material ${ }^{(23)}$. These results point to ethical, legal and professional challenges that permeate the nursing profession. Nurses are free to use social networks in their personal lives, yet they cannot forget that they have both personal and professional identities which are not totally separate or fully fused, but are integrated ${ }^{(55-56)}$. These professionals should understand that what is posted online is likely to be analyzed and or potentially used as a performance evaluation in the future ${ }^{(57)}$. A recommendation would be creating two separate profiles, a professional and a personal one; however, it is important to seriously reflect on the content to be published, regardless of the profile used ${ }^{(57-58)}$. Identification of ethical, legal and professional issues raises the question of whether health professionals need to have a specific orientation issued by regulatory agencies ${ }^{(23)}$.

In the field of academic education, social networks have been effective tools in helping to develop the teaching-learning process, particularly for undergraduate students ${ }^{(33,35,38,46-47)}$, data which corroborate the findings of a national study on the use of social networks in nursing education ${ }^{(19)}$. The 
pedagogical use of social networking technologies as a learning tool is of growing interest to students ${ }^{(33)}$. Studies suggest that social networks increase interaction, collaboration, information, sharing resources and developing critical thinking skills among students. Among the articles selected for this review ${ }^{(33,35,38)}$, the most used social network for this purpose was Facebook, which has university students among the majority of its users ${ }^{(31)}$. It is important to note that social networking websites such as Facebook can give students the opportunity to take part in peer learning where they can autonomously direct and control their learning ${ }^{(38)}$.

Social networks have also been used by nurses to carry out online interventions. Interventions using social networks have achieved important behavioral changes, such as in a study aimed at reducing the incidence of chlamydia among 15 to 17 -year-olds ${ }^{(25)}$. This study found a $54 \%$ reduction in positive chlamydia cases and a $23 \%$ increase in reports of condom use in sexual intercourse through implementing an intervention using Facebook. Advantages of this type of intervention are related to the fact that social networks have the potential to reach hundreds, thousands and even millions of users ${ }^{(25)}$, especially those from younger age groups ${ }^{(31)}$.

Another way to use social networks would be to perform nursing interventions through text messages, which may be especially advantageous for promoting physical activity or eating behaviors, for example ${ }^{(41,44,59)}$. Interventions of this kind have advantages compared to traditional face-to-face interventions, being that the participant does not need to attend the sessions in person and has unlimited access to the intervention materials whenever they wish ${ }^{(41)}$.

No primary studies were found that addressed the use of social networks in administrative or political/policy participation; components of work processes in nursing. Scholars raise some questions about the use of social networks in nursing work environments, which may help nurses who hold management positions to reflect on the subject ${ }^{(60)}$. An important practical implication regarding the use of social networks by nurses is how access should be managed in the clinical context. There are obvious advantages that justify the use of such tools in this scenario, such as improved communication and access to health information based on scientific evidence. However, there are also disadvantages, such as distractions and interruptions ${ }^{(60)}$. Some published guidelines seek to ensure safe and ethical use of social networks by nurses ${ }^{(16)}$, which can provide a reasonable start for establishing the use of social networks in nursing work environments ${ }^{(6))}$.

Regarding political/policy participation, this is a key issue for nurses, after all they are familiar with clinical issues that directly affect health policies at local, state and federal lev$\mathrm{els}^{(61)}$. However, there are many obstacles that prevent nurses from taking a more active role in politics, creating a gap in the way nurses continue and respond to political participation or civic engagement ${ }^{(61)}$. There are reports of the successful use of social networks in political campaigns, for example ${ }^{(62)}$. Social networks can possibly represent a conducive medium for disseminating information and for gathering a large number of people interested in the same cause ${ }^{(62)}$. Nurses can use social networks to unite and to discuss issues related to a category of political participation.
The search in five databases with the descriptors and the keyword presented may have interfered with the obtained results. This review has synthesized evidence on the use of social networks in nursing work processes and provides a guide for nurses to think about the use of such tools in practicing/ exercising their profession, considering that social networks are already a part of everyday life in various fields of society, including health. However, the amount of research on this subject is still limited ${ }^{(41)}$. Thus, further studies should be carried out in order to better understand the use and implications of implementing social networks into nursing work processes.

Many nurses are apprehensive about integrating social media into the profession; however, as society evolves, the nursing profession must do the same ${ }^{(11)}$. Social networks are changing the nature and speed of human interactions, as well as healthcare consumers, professionals and organizations. It is necessary to identify best practices and learn how to use these tools so that they can take full advantage of these new communication platforms ${ }^{(63)}$.

\section{CONCLUSION}

From the analyzed studies we can be affirm that nurses have used social networks such as Facebook, Twitter and WhatsApp to research, teach and assist their work processes, although in an incipient way.

In the field of research, the use of social networks offers benefits such as identifying risk conditions, disseminating information and promoting positive changes in behavior. Also, they improve participants' adherence in longitudinal studies through the contact they provide and in recruiting participants for studies, acting as a platform for communication and support among individuals who are in a similar situation. Social networks may also be a more accessible method for participation in health research and useful in disseminating content on health education. However, ethical considerations regarding the use of social networks for developing research deserve further discussion.

The use of social networks as a tool in the teaching-learning process, especially for undergraduate students, produces benefits in the possibility of sharing academic content and promoting an online environment for developing discussions on varied topics, and in sharing opinions, knowledge and clinical experience.

When compared with traditional face-to-face interventions, those carried out through social networks have the advantage that the participant does not need to attend the sessions in person, and offers unlimited access to the intervention materials whenever they wish.

In this integrative review, no studies were found using social networks for administrating or participating in political activities, elements of nursing work processes. New studies should explore the possibilities offered by social networks for such activities.

It is worth mentioning that there is a lack of national studies on the subject in question. New/further studies with more robust levels of evidence will allow for deeper exploration of the benefits of this technology for developing nursing work processes. 


\section{RESUMO}

Objetivo: Identificar e analisar as evidências disponíveis na literatura sobre a utilização de redes sociais nos processos de trabalho em enfermagem. Método: Revisão integrativa da literatura realizada em janeiro de 2016, nas bases de dados PubMed, CINAHL, EMBASE e LILACS, com os descritores social media, social networking, nursing, enfermagem, redes sociais, mídias sociais e a palavrachave nursing practice, sem restrição de ano. Resultados: A amostra foi composta por 27 artigos, os quais foram publicados entre 2011 e 2016, todos internacionais. As redes sociais utilizadas foram o Facebook (66,5\%), o Twitter (30\%) e o WhatsApp (3,5\%). Em 70,5\% dos estudos as redes sociais foram utilizadas para fins de pesquisa, em 18,5\% como ferramenta para auxiliar estudantes nas atividades acadêmicas, e em 11\% para a realização de intervenções via internet. Conclusão: Em seus processos de trabalho, os enfermeiros têm utilizado as redes sociais Facebook, Twitter e WhatsApp para pesquisar, ensinar e assistir. Os artigos evidenciam diversos benefícios sobre o uso de tais ferramentas na profissão de enfermagem, entretanto, as considerações éticas a respeito da utilização das redes sociais merecem maior discussão.

\section{DESCRITORES}

Enfermagem; Rede Social; Informática em Enfermagem; Revisão.

\section{RESUMEN}

Objetivo: Identificar y analizar las evidencias disponibles en la literatura acerca del empleo de las redes sociales en los procesos laborales de enfermería. Método: Revisión integrativa de la literatura llevada a cabo en enero de 2016, en las bases de datos PubMed, CINAHL, EMBASE y LILACS, con los descriptores social media, social networking, nursing, enfermagem, redes sociais, midias sociais y la palabraclave nursing practice, sin restricción de año. Resultados: La muestra estuvo compuesta de 27 artículos, los que fueron publicados entre 2011 y 2016, todos internacionales. Las redes sociales utilizadas fueron el Facebook (66,5\%), el Twitter (30\%) y el WhatsApp (3,5\%) En el 70,5\% de los estudios, las redes sociales fueron utilizadas a efectos de investigación, en el 18,5\% como herramienta para auxiliar a estudiantes en las actividades académicas, y en el 11\% para la realización de intervenciones por vía Internet. Conclusión: En sus procesos laborales, los enfermeros están utilizando las redes sociales Facebook, Twitter y WhatsApp para investigar, enseñar y asistir. Los artículos evidencian distintos beneficios acerca del uso de dichas herramientas en la profesión de enfermería. Sin embargo, las consideraciones éticas con respecto a la utilización de redes sociales merecen mayor discusión.

\section{DESCRIPTORES}

Enfermería; Red Social; Informática Aplicada a la Enfermería; Revisión.

\section{REFERENCES}

1. Frazier B, Culley JM, Hein LC, Williams A, Tavakoli AS. Social networking policies in nursing education. Comput Inform Nurs. 2014;32(3):110-7.

2. Chyjek K, Farag S, Chen KT. Rating pregnancy wheel applications using the applications scoring system. Obstet Gynecol. 2015;125(6):1478-83.

3. European Travel Commission. NewMedia TrendWatch. World Usage Patterns and Demographics [Internet]. 2013 [cited 2016 May 9]. Available from: http://www.newmediatrendwatch.com/world-overview/34-world-usage-patterns-and-demographics/index.html

4. Ventola CL. Social media and health care professionals: benefits, risks, and best practices. P T. 2014;39(7):491-9.

5. Ressler P, Glazer G. Legislative: nursing's engagement in health policy and healthcare through social media. Online J Issues Nurs. 2010;16(1):11.

6. Childs LM, Martin CY. Social media profiles: striking the right balance. Am J Health System Pharm. 2012;69(23):2044-50.

7. Lambert KM, Barry P, Stokes G. Risk management and legal issues with the use of social media in the healthcare setting. J Healthc Risk Manag. 2012;31(4):41-7.

8. Dizon DS, Graham D, Thompson MA, Johnson LJ, Johnston C, Fisch MJ, et al. Practical guidance: The use of social media in oncology practice. J Oncol Pract. 2012;8(5):114-24.

9. George DR, Rovniak LS, Kraschnewski JL. Dangers and opportunities for social media in medicine. Clin Obstet Gynecol. 2013;56(3):453-62.

10. Fraser R. The nurse's social media advantage: how making connections and sharing ideas can enhance your nursing practice. Indianapolis: Sigma Theta Tau International; 2011.

11. Casella E, Mills J, Usher K. Social media and nursing practice: changing the balance between the social and technical aspects of work. Collegian. 2014;21(2):121-6.

12. Moorley CR, Chinn T. Supporting student nurses in practice with additional online communication tools. Nurse Educ Pract. 2014;14(1):69-75.

13. Health Research Institute. Social media "likes" healthcare: from marketing to social business [Internet]. PwC's; 2016 [cited 2016 Apr 27$].$ Available from: http://www.pwc.com/us/en/health-industries/publications/health-care-social-media.html

14. Cordoş AA, Bolboacă SD. Social media use among nurses: literature review. Stud Health Technol Inform. 2016;225:572-6.

15. Watson J. "The rise of blogs in nursing practice". Clin J Oncol Nurs. 2012;16(2):215-7.

16. Spector N, Kappel DM. Guidelines for using electronic and social media: the regulatory perspective. Online J Issues Nurs. 2012;17(3):1.

17. Asiri $\mathrm{H}$, Househ $\mathrm{M}$. The impact of twitter and facebook on nursing practice and education: a systematic review of the literature. Stud Health Technol Inform. 2016;226:267-70.

18. Sanna, MC. Os processos de trabalho em Enfermagem. Rev Bras Enferm. 2007; 60(2):221-4.

19. Kakushi LE, Évora YDM. Social networking in nursing education: integrative literature review. Rev Latino Am Enfermagem. 2016;24:e2709. 
20. Whittemore R, Knafl K. The integrative review: updated methodology. J Adv Nurs. 2005;52(5):546-53.

21. Ursi ES, Galvão CM. Prevenção de lesões de pele no perioperatório: revisão integrativa da literatura. Rev Latino Am Enfermagem. 2006;14(1):124-31.

22. Melnyk BM, Fineout-Overholt E. Evidence-based practice in nursing \& healthcare: a guide to best practice. Philadelphia: Lippincot; 2005. Making the case for evidence-based practice; p. 3-24.

23. Levati, S. Professional conduct among registered nurses in the use of online social networking sites. J Adv Nurs. 2014;70(10):2284-92.

24. Egan KG, Moreno MA. Prevalence of stress references on college freshmen facebook profiles. Comput Inform Nurs. 2011;29(10):586-92.

25. Jones K, Baldwin KA, Lewis PR. The potential influence of a social media intervention on risky sexual behavior and Chlamydia incidence. J Community Health Nurs. 2012;29(2):106-20.

26. Mychasiuk R, Benzies K. Facebook: an effective tool for participant retention in longitudinal research. Child Care Health Dev. 2012;38(5):753-6.

27. Close S, Smaldone A, Fennoy I, Reame N, Grey M. Using information technology and social networking for recruitment of research participants: experience from an exploratory study of pediatric Klinefelter syndrome. J Med Internet Res. 2013;15(3):e48.

28. Santillán García A. Impact of diffusion of the methodology of evidence-based nursing through Facebook. Rev Enferm (Barcelona). 2013;36(5):36-40.

29. Child RJ, Mentes JC, Pavlish C, Phillips LR. Using Facebook and participant information clips to recruit emergency nurses for research. Nurse Res. 2014;21(6):16-21.

30. O'Connor A, Jackson L, Goldsmith L, Skirton H. Can I get a retweet please? Health research recruitment and the Twittersphere. J Adv Nurs. 2014;70(3):599-609.

31. Labrague LJ. Facebook use and adolescents' emotional states of depression, anxiety, and stress. Health Sci J. 2014;8(1):80-9.

32. Struik LL, Baskerville NB. The role of Facebook in Crush the Crave, a mobile- and social media-based smoking cessation intervention: qualitative framework analysis of posts. J Med Internet Res. 2014;16(7):e170.

33. Tower M, Latimer S, Hewitt, J. Social networking as a learning tool: nursing students' perception of efficacy. Nurse Educ Today. 2014;34(6):1012-7.

34. Mckay M, Sanko JS, Shekhter I, Birnbach DJ. Twitter as a tool to enhance student engagement during an interprofessional patient safety course. J Interprof Care. 2014;28(6):565-7.

35. Morley DA. Supporting student nurses in practice with additional online communication tools. Nurse Educ Pract. 2014;14(1):69-75.

36. Booth RG. Happiness, stress, a bit of vulgarity, and lots of discursive conversation: a pilot study examining nursing students' tweets about nursing education posted to Twitter. Nurse Educ Today. 2015;35(2):322-7.

37. McDaniel PA, Patzke H, Malone RE. Twitter users' reaction to a chain pharmacy's decision to end tobacco sales. Tob Induc Dis. 2015;13:36.

38. Tower M, Blacklock E, Watson B, Heffernan C, Tronoff G. Using social media as a strategy to address 'sophomore slump' in second year nursing students: a qualitative study. Nurse Educ Today. 2015;35(11):1130-4.

39. Akard TF, Wray S, Gilmer MJ. Facebook advertisements recruit parents of children with cancer for an online survey of web-based research preferences. Cancer Nurs. 2015;38(2):155-61.

40. Athanasopoulou C, Sakellari E. Facebook and health information: content analysis of groups related to schizophrenia. Stud Health Technol Inform. 2015;213:255-8.

41. Joseph RP, Keller C, Adams MA, Ainsworth BE. Print versus a culturally-relevant Facebook and text message delivered intervention to promote physical activity in African American women: a randomized pilot trial. BMC Womens Health. 2015;15:30.

42. Niela-Vilén H, Axelin A, Melender HL, Salanterä S. Aiming to be a breastfeeding mother in a neonatal intensive care unit and at home: A thematic analysis of peer-support group discussion in social media. Matern Child Nutr. 2015;11(4):712-26.

43. Odlum M, Yoon S. What can we learn about the Ebola outbreak from tweets? Am J Infect Control. 2015;43(6):563-71.

44. Valle CG, Tate DF, Mayer DK, Allicock M, Cai J. Exploring Mediators of Physical Activity in Young Adult Cancer Survivors: Evidence from a Randomized Trial of a Facebook-Based Physical Activity Intervention. J Adolesc Young Adult Oncol. 2015;4(1):26-33.

45. Wittenberg-Lyles E, Washington K, Oliver DP, Shaunfield S, Gage LA, Mooney M, et al. "It is the 'starting over' part that is so hard": Using an online group to support hospice bereavement. Palliat Support Care. 2015;13(2):351-7.

46. Willemse JJ. Undergraduate nurses reflections on WhatsApp use in improving primary health care education. Curationis. 2015;38(2):1512.

47. Waldrop J, Wink D. Twitter: an application to encourage information seeking among nursing students. Nurse Educ. 2016;41(3):160-3.

48. Richardson J, Grose J, Nelmes P, Parra G, Linares M. Tweet if you want to be sustainable: a thematic analysis of a Twitter chat to discuss sustainability in nurse education. J Adv Nurs. 2016;72(5):1086-96.

49. Nielsen. State of the Media. The Social Media Report 2012 [Internet]. 2012 [cited 2016 Sept 18]. Available from: http://www.nielsen.com/ content/dam/corporate/us/en/reports-downloads/2012-Reports/The-Social-Media-Report-2012.pdf

50. Twitter. Uso do Twitter. Fatos sobre a empresa [Internet]. 2015 [citado 2016 maio 09]. Disponível em: https://about.twitter.com/pt/company

51. Montag C, B1aszkiewicz K, Sariyska R, Lachmann B, Andone I, Trendafilov B, et al. Smartphone usage in the 21 st century: who is active on WhatsApp? BMC Res Notes 2015;8:331.

52. Johnston MJ, King D, Arora S, Behar N, Athanasiou T, Sevdalis N, et al. Smartphones let surgeons know WhatsApp: An analysis of communication in emergency surgical teams. Am J Surg. 2015;209(1):45-51. 
53. Moreno MA, Fost NC, Christakis DA. Research ethics in the MySpace era. 2008;121(1):157-61.

54. Boyd D. Internet inquiry: conversations about method. Thousand Oaks, CA: Sage; 2008. How can qualitative Internet researchers define the boundaries of their projects: a response to Christine Boyd; p. 26-332.

55. National Council of State Boards of Nursing. A nurse's guide to the use of social media. Chicago: NCSBN; 2011.

56. American Nurses Association. Code of ethics for nurses with interpretive statements: interpretation and application. Maryland: Silver Spring; 2001.

57. Clark JR. Legal matters: do you still "like" Facebook? Air Med J. 2013;32(4):184-7.

58. Walaski P. Social media: powerful tools for SH\&E professional. Prof Saf [Internet]. 2013 [cited 2016 Apr 22];58(4):40-9. Available from: https://www.asse.org/assets/1/7/F1Wala_0413.pdf

59. Laranjo L, Arguel A, Neves AL, Gallagher AM, Kaplan R, Mortimer N, et al. The influence of social networking sites on health behavior change: a systematic review and meta-analysis. J Am Med Inform Assoc. 2015;22(1):243-56.

60. Piscotty R, Voepel-Lewis T, Lee SH, Annis-Emeott A, Lee E, Kalisch B. To tweet or not to tweet? Nurses, social media, and patient care. Nurs Manage. 2013;44(5):52-3.

61. Woodward B, Smart D, Benavides-Vaello S. Modifiable factors that support political participation by nurses. J Prof Nurs. 2016;32(1):54-61.

62. Goodman J, Wennerstrom A, Springgate BF. Participatory and social media to engage youth: from the Obama campaign to public health practice. Ethn Dis. 2011;21(3 Suppl 1):94-9.

63. Miller ET. How social media affects our practice. Rehabil Nurs. 2013;38(6):273-4. 